Article

\title{
Political Participation and Power Relations in Egypt: The Scope of Newspapers and Social Network Sites
}

\author{
Mostafa Shehata \\ Department of Communication and Arts, Roskilde University, 4000 Roskilde, Denmark; E-Mail: shehata@ruc.dk
}

Submitted: 31 January 2017 | Accepted: 27 March 2017 | Published: 8 May 2017

\begin{abstract}
The political use of media in Egypt post-2011 revolution brought about drastic transformations in political activism and power structures. In the context of communication power theory, this article investigates the effects of newspapers and social network sites on political participation and political power relations. The research employed a mixed methodology, comprised of a survey of 527 Egyptian youth and semi-structured interviews of 12 political activists and journalists. The results showed a significant relationship between reading newspapers and youth's political participation, but not between using social network sites and political participation. In addition, newspapers and social network sites were platforms for a series of conflicts and coalitions that emerged between pro- and anti-revolution actors. Despite the importance of social network sites as key tools for informing and mobilizing the public, they eventually failed to empower new political actors, and this was because old actors, supported by newspapers and other mainstream media, managed to obstruct the new actors' progress.
\end{abstract}

\section{Keywords}

communication power; Egyptian newspapers; Egyptian political actors; mediatization of politics; political participation; politicizing newspapers; power relations; social network sites

\section{Issue}

This article is part of a multidisciplinary issue of Media and Communication, edited by Epp Lauk (University of Jyväskylä, Finland) and Raul Reis (Emerson College, USA).

(C) 2017 by the author; licensee Cogitatio (Lisbon, Portugal). This article is licensed under a Creative Commons Attribution 4.0 International License (CC BY).

\section{Introduction}

The authoritarian nature of Mubarak's rule in Egypt substantially obstructed Egyptian youth's political participation (PP) for decades. In the last two parliamentary elections under his rule (held in 2005 and 2010), voter turnout did not exceed $23 \%$ and $15 \%$ respectively (Sika, 2012 , p. 138). In contrast, youth protest activities considerably increased in the final years of his reign, culminating in the January 2011 revolution (25J) that managed to topple him on February 11th of the same year. In the wake of the revolution, Egyptians started to actively participate in politics in different respects. For example, voter turnout in the 2011 referendum and parliamentary election comprised $41 \%$ and $60 \%$ respectively (Abd Alsamad, 2014, paras. 2-4). However, PP was once again obstructed when the army seized power after ousting the Muslim Brotherhood (MB) affiliated president Mohamed Morsi on July 3rd, 2013. This obstruction was characterized mainly by repression of the revolution's advocates, in return for reinforcing its opponents (Khalifa, 2015, p. 216).

In addition to the rapid transformation of PP post25J, the Egyptian political scene also witnessed a related transformation in the power structure of political actors. The fall of Mubarak's National Democratic Party in the wake of the revolution allowed for the emergence and rise of pro-revolution actors, such as revolutionary youth and the MB (Mason, 2013; Meier, 2011). Since that time, these actors have mostly collided with anti-revolution actors such as the army and remnants of the Mubarak regime. Consequently, a series of conflicts and coalitions have emerged between all these actors, and these have thwarted chances for a democratic transition.

In the midst of post-revolution political changes, Egyptian newspapers (both offline and online) and social network sites (SNS) have played a significant role in effecting changes in PP and power structures. On the 
one hand, the overall attitudes of newspapers toward the revolution's outcomes have substantially fluctuated (AlMaskati, 2012; Hamdy \& Gomaa, 2012). In general, it can be said that newspapers, which have mostly been controlled by anti-revolution actors, have opposed the 25J, especially since July 3rd, 2013 (El-Adawy, 2014; Roll, 2014). On the other hand, SNS have largely been used by pro-revolution actors, both during and after 25J, as key mobilization platforms (Khamis, Gold, \& Vaughn, 2012). For this reason, several scholars have considered SNS influential tools for changing societies (e.g. Aouragh, 2012; Aouragh \& Alexander, 2012; ElNawawy \& Khamis, 2012). In order not to overestimate their political effect, we can initially say that SNS have represented alternative platforms that have disclosed what traditional media have concealed (Abdulla, 2014, p. 1).

This article raises the question of how newspapers and SNS might have affected youth's PP and empowered revolutionary youth (as an emerging political actor) amidst other political actors following 25J. The first part of this two-sided question is addressed quantitatively, based on the definition of PP as the "activity that has the intent or effect of influencing government actioneither directly by affecting the making or implementation of public policy or indirectly by influencing the selection of people who make those policies" (Verba, Schlozman, \& Brady, 2002, p. 38). In this respect, PP is examined through the various kinds of political activities in which youth participated, such as voting, protesting, volunteering, and donating.

The second part of the research question, which focuses on the role of media in the power relations of political actors, is addressed qualitatively in the context of the theory of communication power. Conceptually, Manuel Castells (2009) defines power as: "the relational capacity that enables a social actor to influence asymmetrically the decisions of other social actor(s) in ways that favor the empowered actor's will, interests, and values" (p. 10). $\mathrm{He}$ also theorizes the relation between media and power by arguing that "power is primarily exercised by the construction of meaning in the human mind through processes of communication enacted in global/local multimedia networks of mass communication, including mass self-communication" (Castells, 2009, p. 416). In this context, this article investigates the nature of political relations between major political actors and the potential effects of newspapers and SNS in that regard. Hence, I argue that SNS cannot, in the long run, empower new political actor(s) especially if newspapers and other mainstream media are under the control of old actor(s).

\section{Literature Review}

\subsection{Newspapers and Political Participation}

The Egyptian newspaper landscape includes three major types: government-owned newspapers, which are loyal to the government; partisan newspapers, which enjoy some freedom in their handling of the government; and private newspapers, which are more free and professional (Allam, 2010, paras. 5-8). However, it is important to mention that the freedom of each type, which improved in the wake of the $25 \mathrm{~J}$, has considerably declined since July 3rd, 2013. Since this date, all newspapers have adopted and adhered to the country's official ideology (Abdulla, 2014, pp. 11-27).

The literature of PP has largely investigated whether reading newspapers relates to youth's PP. In this context, some studies have found no significant relationship between these variables (e.g. Gorsche, 2002; Wang, 2002; Wright-Phillips, 2010), while others have found a significant relationship between them (e.g. Bakker \& De Vreese, 2011; Fawzy, 2008; Moeller, De Vreese, Esser, \& Kunz, 2014; Shehata, 2010). Unexpectedly, findings of a relationship between newspapers and PP prove that newspapers are still able to affect youth, although youth have primarily become more interested in using SNS. Linking these results to the Egyptian case in the current study, we should expect the opposite results, as a large proportion of Egyptians have lost confidence in newspapers, which have become biased and loyal to the government.

With respect to newspapers' coverage of PP activities, a number of studies have found that Egyptian newspapers, in general, adopt negative attitudes toward protestors and participation (e.g. AlMaskati, 2012; Hamdy \& Gomaa, 2012; Ibrahim, 2012; Youssef, 2012). The main exception to this is provided by Khamis (2011, pp. 1161-1162), who found that private newspapers kept people informed about negativities and protest activities, both before and during 25J. In general, the policies of Egyptian newspapers have changed several times, perhaps as a result of the four power transitions that have occurred over the last six years. In order to holistically understand the conditions of these changes, this article highlights the relationship between newspapers and political actors, which is expected to be a significant factor behind such changes.

\subsection{Social Network Sites and Political Participation}

Overall, SNS have provided Egyptian youth with a real opportunity to express themselves politically. SNS have also compensated for youth's absence from mainstream media, which have been inaccessible to them (Howard \& Hussain, 2013, pp. 4-5). However, the political role of SNS in Egypt has been affected by government censorship, especially in the last three years. As SNS are no longer free in Egypt (as they were previously, in the wake of Mubarak's ouster), it is important to investigate the impacts of SNS censorship on PP and revolutionary youth's power.

With respect to the relationship between using SNS and PP, the literature has produced three different findings: (1) SNS play a key role in PP forms (e.g. Holt, Shehata, Strömbäck, \& Ljungberg, 2013; Kamel, 2014; 
Khamis \& Vaughn, 2011; Meier, 2011; Rice, Moffett, \& Madupalli, 2012; Schuster, 2013; Valenzuela, 2013); (2) the relationship is contingent upon a number of intervening variables, such as social and cultural background (Groshek, 2008), old media consumption (Budak, 2010), face-to-face communication (Vissers, Hooghe, Stolle, \& Mahéo, 2012), membership in interest organizations (Gustafsson, 2012), dissatisfaction with the government (Harrebye \& Ejrnæs, 2015), and socioeconomic status (Oser, Hooghe, \& Marien, 2013); and (3) the relationship is doubtful (Dimitrova \& Bystrom, 2013; Schlozman, Verba, \& Brady, 2010).

As a result of the Arab Spring (AS) and similar movements in other countries, assessment of the effects of SNS on PP and power structures in the last years has been very optimistic. However, some very recent writings (e.g. Fenton, 2016) on this subject have re-assessed the effects of SNS in the light of the obstacles of the democratic transition in AS countries. Accordingly, in this article, SNS are handled as neither a main reason for PP nor a main source of empowerment for political actors. Rather, they are handled as platforms for participation and power relations, and the doubts raised about their effects are also considered.

\subsection{Power Relations and Network Society}

In his theory of communication power, Castells (2009) describes mass communication and Internet-based communication as processes through which power can be practiced, and he considers power, itself, as relations between different actors. In this context, Howard (2010, p. 12) claimed that technology can provide political actors new capacities and restrictions, but it cannot achieve political change. This claim was empirically supported by Meier (2011), who found that communication technology threatened the political regime in Egypt and shifted the balance of power in favor of civil society. However, it should be noted that the rise of civil society (including revolutionary youth) in Egypt did not last beyond June 2013; since that time, old actors have resurged. This article will further explain the conditions of this setback and the effects of newspapers and SNS in that regard.

The landscape of political actors in Egypt post-25J has diversified, according to El-Adawy (2014), into three major categories: formal institutions, informal societal actors, and executive authority. The latter has depended, as described by Roll (2014), upon three further main actors: Arab Gulf countries, the army, and the country's business figures. Among these actors, three major political coalitions were, as noted by El-Dine (2014), formed post-25J: (1) the army and the MB; (2) the army and the National Salvation Front, which were formed against the MB; and (3) the army, the business elite, the Salafist Nour party (the Light), and secular forces. In my opinion, a separation of formal institutions, executive authority, and the army, as suggested by El-Adawy (2014) and Roll (2014), does not apply to the Egyptian case, because the army has had the upper hand over all other institutions, including the government. Thus, in this article, the army will be handled as a major actor alongside the MB and revolutionary youth.

With respect to the relationship between the media and political actors, El-Adawy (2014) and Roll (2014) found that media outlets joined political forces to encourage people to demonstrate on June 30th, 2013 against the ousted president Morsi. In a similar context, Khamis et al. (2012) found that political activists used online and offline activism in their conflict with the post-Mubarak regime, which used both state-owned and social media. These results prove Castells' claim about the importance of communication networks for political power and counter-power (Castells, 2011, p. 783). They also raise the issue, which this article discusses, of the difference between the effects produced by traditional media versus those produced by new media on political actors, and the limitations of these effects.

\section{Methodology}

The empirical data of this study were collected through a mixed-method approach combining survey and semistructured interviews using a convergent parallel design. Based on this approach, first, quantitative and qualitative data were collected concurrently to complement each other; later, the data were separately analyzed; and finally, points of analysis were synthesized to achieve the purpose of the study (Creswell \& Plano Clark, 2011, pp. 77-81).

\subsection{Survey}

The survey was based on a face-to-face questionnaire (Foreman, 1991; Wimmer \& Dominick, 2011) that was conducted in September and October 2015. The sample included 527 Egyptians aged 18 to 35 . Only 400 questionnaires were used for a statistical analysis using the Statistical Package for Social Sciences, version 23 for Macintosh. The sample size was calculated by two methods described by Israel (1992, pp. 3-4), based on which the number of respondents was determined.

The respondents were chosen deliberately after using a proportional allocation considering gender $(51 \%$ male and $49 \%$ female) and place of residence $(57.75 \%$ from Cairo, $24.50 \%$ from Menoufia and $17.75 \%$ from Beni Suef). These governorates were specifically selected to represent three geographical and cultural aspects in Egypt. While Cairo is the capital and includes more urban and culturally modern inhabitants, Menoufia represents the northern part of the country, which is slightly culturally conservative, and Beni Suef represents the southern part of the country, which is more conservative. It is also noteworthy that a pre-test was applied in order to enhance the validity and relevance of the questionnaire.

In addition, the quantitative phase of this article developed three scales: newspaper readership, SNS expo- 
sure, and political participation. The first scale, newspaper readership, was modified from the scale described by Williams (2008, p. 163), which included two items: online and offline reading of eight of the most common Egyptian newspapers. In both items, each newspaper was rated on a four-point response format, where $0=$ do not read it, $0.25=$ read it a few times a year, $0.5=$ once $a$ month, $1=$ a few times a month, $2=$ once a week, $3=a$ few times a week, and $4=$ daily or approximately daily. Thus, the range of the total score was from 0.25 to 72 . Respondents were classified into three categories on the basis of their scores $(s)$ : low reading $(s<6)$, moderate reading $(6 \leq s \leq 11)$, and high reading $(s>11)$. Cronbach's $\alpha$ coefficient, which was adopted to test the internal consistency of the scale, was 0.727 .

The second scale, SNS exposure, was modified from the commonly used scale of Ellison, Steinfield and Lampe (2007, p. 1150), and included three items. (1) The time consumed using three SNS (Facebook, Twitter and YouTube): this item was rated on a three-point response format for each website, where $0=$ no time at all, $1=$ less than 30 minutes, $1.5=30-59$ minutes, $2=1$ hour up to 2 hours, $2.5=$ more than 2 hours up to 3 hours, and $3=$ more than 3 hours. (2) The number of friends, followings and subscriptions: this item was also rated on a three-point response format for each website, where $0=$ do not use it, $1=$ fewer than $50,1.5=50-149$, $2=150-299,2.5=300-449$, and $3=450$ or more. And (3) attitudinal relation to SNS: this item, which was examined by six sentences, was likewise rated on a three-point response format for each sentence, where $1=$ strongly disagree, $1.5=$ disagree, 2 = neutral, $2.5=$ agree, and $3=$ strongly agree. Before the overall score of this scale was calculated, the three items were statistically standardized, because they used different measurement units. Based on this process, the three items were converted to a $z$ score, then a composite of $z$ scores was computed (Anglim, 2009), and finally the composite score was converted to a scaled score (Richard, 2010, pp. 14391440). Accordingly, the range of the total score of this scale was from 1 to 19 , based on which exposure to SNS was classified into three categories: low exposure $(s<8,48)$; moderate exposure $(8.48 \leq s \leq 11.44)$; and high exposure $(s>11.44)$. In addition, Cronbach's $\alpha$ coefficient, based on the standardized items, was 0.791 .

The third scale, political participation, consisted of three different sub-scales. (1) PP aspects, which was guided by Verba et al. (2002, pp. 544-545) and included the following eight political activities in which respondents might have participated in the two years preceding the survey (June 2013-June 2015):

- Voting in the last presidential or parliamentary elections;

- working in electoral campaigns in the last presidential or parliamentary elections;

- contacting government officials within the past year;
- taking part in protests, strikes or sit-ins within the past two years;

- working informally with others to solve community problems within the past year;

- being politically active through a voluntary association within the past two years;

- serving voluntarily in a local governmental board regularly within the past two years; and

- being a member of, or donating to, a political organization within the past year.

Each item was rated on a one-point format, where $0=$ no and $1=$ yes. (2) Interest in local politics and affairs. And (3) interest in national politics and affairs. These latter two sub-scales, which were also guided by Verba et al. (2002, p. 553), were rated on a three-point response format, where 3 = very interested, 2 = fairly interested, $1=$ not very interested, and $0=$ not at all interested. The score of each sub-scale was standardized using the same procedures that were described for the previous scale. Consequently, the range of the total score of this scale was from 1 to 19 , based on which the levels of PP were classified into three categories: low participation $(s<8,5)$; moderate participation $(8.5 \leq s \leq 11)$; and high participation ( $s>11$ ). Cronbach's $\alpha$ coefficient, based on the standardized items, was 0.574 .

\subsection{Semi-Structured Interviews}

Initially, three online pilot interviews were conducted to develop an interview protocol guide. Following this, 12 semi-structured interviews were conducted in person in October 2015. The interviewees included four political activists and eight political journalists (two of whom could also be considered activists to a lesser degree). The categories of journalists and activists were particularly selected as those that were related to and informed about media and politics. The selection of interviewees drew mainly on a snowball sampling method, wherein early interviewees were asked to provide referrals to other relevant respondents (Blernackl \& Waldorf, 1981, p. 141). This method facilitated reaching respondents especially political activists who had likely been placed under security surveillance.

The interview protocol guide included questions that were planned in advance to cover major points, such as PP developments post-25J, newspapers/SNS and PP, and the power relations of political actors. In addition, many further questions that emerged during the interviews were asked as well. It is noteworthy that a few number of newspaper clippings and SNS posts were shown to interviewees in order to enrich discussion of the study topic.

All interviews, which were conducted in Arabic, were transcribed and translated into English using NVivo software, version 11, for Macintosh. Following this, a grounded theory method was used for the analysis. This method did not aim to generate a theory, but to identify the key concepts and categories of the transcripts and to 
investigate the relationships between them. In this context, the method aimed to provide an in-depth understanding of the relationship between newspapers/SNS with PP and power relations over the previous six years. The results were used to complement and interpret the results of the quantitative phase of this study.

Data analysis was carried out in a three-step coding process. First, open coding was conducted line by line on all transcripts, in order to determine general points and themes. Second, axial coding was used to combine sets of codes in categories and sub-categories. This process was repeated until no new categories emerged. At this stage, all categories were constructed after their codes and concepts were read many times and it was certain that every category contained homogenous components. Third, selective coding was conducted to develop the categories and to identify core category(ies) (Corbin \& Strauss, 1990, pp. 12-15; see also Glaser \& Strauss, 1967, pp. 105-107; Strauss \& Corbin, 1998, pp. 101-161). Alongside and after the coding process, many ideas were written down in memos in order to identify the relationships between themes and categories and to extract the explicit and implicit meanings of such relationships. This was important for eliciting and illustrating participants' views and forming a conceptual link between them (Charmaz, 2006, p. 72).

\section{Results}

\subsection{Quantitative Analysis}

Starting with the intensity of reading Egyptian newspapers (offline and online), the results found that about two-thirds (71\%) of the respondents read newspapers, while less than a third (29\%) did not read them. Among the readers, more than one-third (41.2\%) achieved a high level of readership, about one-third (33.1\%) had a moderate level, and about a quarter $(25.7 \%)$ achieved a low level. These results indicate that Egyptian youth read newspapers in a relatively high rates; this can be ascribed to their high exposure to the Internet, as well as to the political polarization post-25J. With regard to PP levels, the results found that moderate participation came in the first place with $46.5 \%$, followed by low participation with $28.2 \%$ and high participation with $25.3 \%$.
More significantly, the correlation between reading newspapers and political participation was examined using a non-parametric test (Spearman's rho). As shown in Table 1, the results found a significant positive relationship between the two variables $\left(r_{s}[284]=.131\right.$, $p=.027)$ : as reading newspapers increases PP increases, and as reading decreases PP decreases. These results agree with the findings of previous studies (e.g. Bakker \& De Vreese, 2011; Fawzy, 2008; Moeller et al., 2014; Shehata, 2010), which have found a significant relationship between reading newspapers and PP. However, the findings disagree with some other studies (e.g. Gorsche, 2002; Wang, 2002; Wright-Phillips, 2010), which have found no such relationship between the variables.

With respect to the intensity of using SNS, the results indicated that the vast majority of respondents (97\%) used SNS-especially Facebook, Twitter and YouTubewhile only $3 \%$ did not use them. Among the users, exactly half of them (50\%) used SNS at a moderate level, while slightly more than a quarter (25.5\%) used them at a high level, and slightly less than a quarter (24.5\%) used them at a low level. These results indicate that a relatively large proportion of Egyptian youth were highly exposed to SNS that were strong social and political platforms.

Furthermore, the correlation between SNS exposure and PP was examined using a non-parametric test (Spearman's rho). Unexpectedly, the results found no significant relationship between the two variables $\left(r_{s}[388]=.081, p=.111\right)$ (Table 2). The Levels of using SNS were not associated with the levels of PP, which resulted in the elimination of the effects of SNS on youth's PP. These results agree with the results of previous studies (e.g. Dimitrova \& Bystrom, 2013; Schlozman et al., 2010), though they disagree with the results of some other studies (e.g. Holt et al., 2013; Kamel, 2014; Khamis \& Vaughn, 2011; Meier, 2011; Rice et al., 2012; Schuster, 2013; Valenzuela, 2013).

Comparing the relationships of both newspapers and SNS with youth's PP revealed that newspapers correlated significantly with PP, while SNS did not. The lack of a significant relationship between SNS and PP can be ascribed to the fact that participation was quantitatively examined for the two years preceding the questionnaire (June 2013 to June 2015), during this time period, all major political actions were undemocratic. SNS users were obvi-

Table 1. The relationship between newspaper readership and political participation.

\begin{tabular}{lllcc}
\hline & & Levels of readership & Levels of PP \\
\hline Spearman's rho & Levels of & Correlation coefficient & 1.000 & $.131^{*}$ \\
& readership & Sig. (2-tailed) &. & .027 \\
& $\mathrm{~N}$ & Correlation coefficient & 284 & 284 \\
\cline { 2 - 5 } & Levels of PP & Sig. (2-tailed) & $.131^{*}$ & .027 \\
& $\mathrm{~N}$ & 284 &. \\
& & & 4000 \\
\hline
\end{tabular}

*. Correlation is significant at the 0.05 level (2-tailed). 
Table 2. The relationship between using SNS and political participation

\begin{tabular}{lllcc}
\hline & & Levels of using SNS & Levels of PP \\
\hline Spearman's rho & Levels of & Correlation coefficient & 1.000 & .081 \\
& using SNS & Sig. (2-tailed) &. & .111 \\
& $\mathrm{~N}$ & Correlation coefficient & 388 & 388 \\
\cline { 2 - 5 } & Levels of PP & Sig. (2-tailed) & .081 & .111 \\
& $\mathrm{~N}$ & 388 &. \\
& & & 4000 \\
\hline
\end{tabular}

*. Correlation is significant at the 0.05 level (2-tailed).

ously opposed to such actions. In contrast, the significant relationship found between reading newspapers and PP can be attributed to the fact that newspapers discourse was in line with undemocratic actions, which likely encouraged readers to participate.

Furthermore, political affiliation was examined to determine whether it yielded significant differences in PP levels. Using the non-parametric test of Kruskal-Wallis, the results found no significant differences between the two variables $\left(\chi^{2}(2, N=97)=.554, p=.758\right)$. This can be explained by three main factors: (1) most Egyptian youth do not tend to involve themselves in political parties or movements; (2) political parties and movements have been under government control for decades, and are also ineffective; and (3) the recent political actions in Egypt have been found to be connective actions (Shehata, 2017). According to Bennett and Segerberg (2012), most participants in connective actions tend to be unaffiliated, and these actions are likely moderated by communication technologies without interference from organizational actors (p. 755). This helps individuals (including youth) emerge as a political actor in the face of counteractors. In this way, SNS can empower political actors. This supports Castells' claim about the importance of mass media and Internet-based media for practicing power (Castells, 2009, p. 416). However, his is not an absolute claim, because the importance of SNS or even newspapers for structuring power relations and empowering political actors is contingent upon several factors, such as government repression and media censorship. In the following section, the discussion will seek more evidences to support or refute this claim.

\subsection{Qualitative Analysis}

The coding schemes of grounded theory yielded 803 codes, which represented the core ideas of the interviews transcripts. These codes were grouped into 33 categories and subcategories. Following this, two main categories were emerged from the analysis: fluctuation of PP; and power relations of political actors. Both categories were handled in relation to newspapers and SNS over the previous six years.

Starting with the fluctuation of PP, most interviewees pointed out that the youth's participation increased during and after 25J. This participation manifested in in- creased involvement in political parties, entities, and civil society organizations, and participating in protests and elections. However, since July 3rd, 2013, PP had been fundamentally thwarted by the governments. The lack of participation since then was best described and explained by the prominent political activist N. Abd Alhamid (personal communication, October 22nd, 2015), who told me in a despairing tone:

Youth didn't run for elections; they didn't participate! You're talkin' about youth who have been distorted for two years!

You're talkin' about the $25 \mathrm{~J}$ that has been distorted for two or three years!

You're talkin' about youth who have been excluded from political work!

You're talkin' about jailed people!

So, it is normal not to have a youth participation.

\subsubsection{The Effects of Newspapers/SNS on Political Participation}

Alongside the power transformations that occurred several times in post-25J Egypt, newspapers' attitudes toward the revolution and political actors rapidly changed. While newspapers supported the revolution and revolutionary youth in the wake of Mubarak's ouster, they turned against the revolution after July 3rd, 2013. This shift, as one interviewee stated, was normal in a context in which "media career in Egypt is subjected to two limitations: the extent of subordination to political authority; and, in a greater degree, the capital of the media" (A. Abdeen, personal communication, October 12th, 2015). This result agrees with Abdulla's study (2014), which also ascribed this shift to the changes in newspapers' freedom, which increased after 25J and declined after July 3rd, 2013.

Egyptian newspapers have suffered from both external and internal restrictions, especially since July 3rd, 2013. Whereas the former restrictions have manifested in security censorship, the latter restrictions have manifested in the self-censorship of editors-in-chief. Under these restrictions, many newspapers have suffered, according to the Freedom House (2016), from confiscation, banning issues, deterring writers from writing, and the imprisonment of journalists. Such restrictions have 
forced all newspapers to adopt a pro-government editorial policy, with very few exceptions, such as weak online newspapers such as Bawabt Yanayer (January Gate), Albedaya (The Beginning) and Albadil (The Alternative).

In a very significant testimony about the security interference, the journalist M. Al-kholy (personal communication, October 8th, 2015) revealed, "we received here in our newspaper a letter from the Defense Ministry stating that 'we'd like you not to publish any news about Sinai [the northeastern part of Egypt in which the army is fighting against terrorist groups] except the official statements issued by the Ministry's Department of Moral Affairs'." With regard to internal restrictions, the political activist and journalist S. Sayed (personal communication, October 20th, 2015), for example, talked about her personal experiment with newspapers' internal restrictions:

I remember when I was working at Al-badil newspaper, I once uploaded a video and photos on Facebook entitled "MB demonstrations". In a very serious tone, my head of the department shouted at me and said "Don't you ever write the name of MB, you must append it with the term of terrorist group, this is an order for all newspapers."

In contrast to newspapers, SNS have been the main informational and mobilizational platforms for many political actions post-25J. In this regard, they have bridged the gap left by the government's control of mainstream media. However, the power transition since July 3rd, 2013 has negatively affected SNS. One such negative effect, for example, is that the use of SNS for opposition activities has increasingly become a case that might lead users to prison. As one interviewee noted, "there are more than one trial case, as published in newspapers, in which posting offensive content against the army or the country was between the seizures" (M. Al-kholy, personal communication, October 8th, 2015). As a result, the political effect of SNS has declined, although their ability to spread political awareness has increased (A. Dabbour, personal communication, October 15th, 2015).

In addition, most interviewees noticed that SNS had transformed from being platforms for political mobilization to being tools for political sarcasm and the defense of human rights. In this context, the prominent Journalist T. Abo Arab (personal communication, October 7th, 2015) noted:

Now on Facebook there're no calls for protests, taking attitudes toward elections or overthrowing someone, because politics is no longer existent. The alternative is that SNS have become focusing on human rights and people's issues, and they've turned into a media channel that publishes what other media channels ignore.

The transformation of SNS from mobilization channels to human rights defenders adds a new dimension to the study of Alexander and Aouragh (2014), which found that online media are no longer primary platforms for transferring the activities and voices of specific revolutionary groups. More importantly, the transformations in attitudes of both newspapers and SNS toward PP coincided with and followed the transfer of political authority. Consequently, we can assume that the attitudes of newspapers and SNS toward PP related to authority transfer.

\subsubsection{The Effects of Newspapers/SNS on Power Relations}

The interviews had a special focus on the relationship of newspapers and SNS with the power relations of political actors post-25J. Initially, most interviewees agreed on the major actors, which included the army, the MB, revolutionary youth, remnants of the Mubarak regime, and, to a lesser degree, political parties. The prominent political activist S. Diab (personal communication, October 23rd, 2015) classified political actors into three groups:

The political field in Egypt includes three sides: the country, not only the army but all institutions and those who belong to them; political Islam side, not only the Brotherhood but all Islamic actors; and civil side. Within every side there're influential and uninfluential actors....If two of these three sides allied against the third, they defeat it.

Based on the effectiveness of political actors, the previous six years could be divided, according to most interviewees, into three chronological stages: (1) from Mubarak's ouster on February 11th, 2011 to the beginning of 2012, when revolutionary youth, liberal actors, and leftist actors were a striking force in political activism; (2) from the beginning of 2012 to June 2013, when Islamic actors-including the MB and the Salafiswere a leading force in parliament and the presidency; and (3) after Morsi's ouster on July 3rd, 2013, when the army, remnants of the Mubarak regime, and business elite controlled all of the country's institutions.

Although it had only been a short period since the eruption of the revolution, political authority had been transferred several times, and with each transfer, the landscape of political coalitions and conflicts profoundly changed. During the revolution, a very short-term and spontaneous political coalition was formed between the revolutionary youth and the $\mathrm{MB}$. This coalition cracked in March 2011, when the Brotherhood entered into an implicit coalition with the army. This new coalition completely broke down on June 30th, 2013, when the army joined a new coalition with the remnants of the Mubarak regime and a large portion of the civil forces and business elite. This latter new coalition managed to oust the MB from power on July 3rd, 2013, and following this, it massively repressed the $\mathrm{MB}$ and turned against revolutionary youth. Consequently, the three main actors (the army, the $\mathrm{MB}$, and revolutionary youth) became separate and 
strongly conflicted. Accordingly, it can be said that the development of political relationships constructed the power and counter-power of political actors. In other words, political coalitions enabled allied actors to exert power over other actors. This analysis supports one of Castells' central claims that considers power as relationships between actors (Castells, 2009, p. 10).

Newspapers and SNS were indeed platforms upon which conflict and cooperation relationships were centered. On the one hand, newspaper ownership played a crucial role in shaping political discourse and affecting PP activities. According to the prominent activist I. Abd Alfatah, newspapers that are owned or controlled by major political actors spark conflict relationships. While the army has almost controlled all types of newspapers, the MB-owned Alhoriya Wa Aladala (The Freedom and Justice), and the revolutionary youth have worked at some newspapers, through which they have expressed their views (I. Abd Al-fatah, personal communication, October 10th, 2015).

In addition, as most newspapers have been controlled by anti-revolution actors (the army, remnants of the Mubarak regime, and the business elite), their attitudes have been very negative toward the revolutionary youth and protest activities. This consequently has, as noted by M. Al-kholy (personal communication, October 8th, 2015), negatively affected newspapers' credibility for citizens, who no longer trust them. These results agree with those of some studies (e.g. AlMaskati, 2012; Hamdy \& Gomaa, 2012; Ibrahim, 2012; Youssef, 2012), which have found that newspapers have adopted negative attitudes toward protestors and participation activities.

On the other hand, SNS have been key tools for political information and mobilization. Revolutionary youth, in particular, have been superior in using them to organize protest activities. However other political actors have started to use SNS for counter-mobilization and shaping public opinion. In this context, T. Abo Arab (personal communication, October 7th, 2015) stated:

Primarily, before the 25J, Facebook was mostly used by liberal activists, while the $\mathrm{MB}$ and the army were out of it. Straight after the revolution, the MB, followed by the army, started to use it intensively. The conflict between the MB and the army, therefore, moved to SNS. Both of the actors have had electronic teams that rivalled revolutionary youth online.

Going back to the argument of the inability of SNS to empower revolutionary youth in the long run, we can say, in light of this analysis, that SNS enabled the youth to transfer their voices, to provide different narratives of political actions, and to mobilize people for protests. As an emerging political actor, revolutionary youth could do this when they were the main users of SNS, which were also more free. But these conditions changed, and the ability of SNS to empower youth was affected by at least four determinants: access of other actors to SNS, the government's censorship of SNS, the government's control of mainstream media, and the political repression following July 3rd, 2013. As a consequence, the ability of SNS to give rise to revolutionary youth has considerably declined, leaving its ability to empower them in the long run very much in doubt.

This analysis disagrees with the results of some studies (e.g. Alexander \& Aouragh, 2014, p. 892; Meier, 2011), which have shown that the Internet has shifted the power balance in favor of pro-revolution actors in Egypt. However, this does not necessarily mean that SNS have not been important for new political actors. Indeed, SNS and the Internet have been essential for playing, at least, two other roles: increasing tensions within the overall structure of power (Curran, 2002, p. 65) and making power (Castells, 2009, p. 416). These roles have not been maintained or translated into long-term empowerment by revolutionary youth.

\section{Discussion}

The quantitative analysis found that newspapers, but not SNS, related significantly with PP. The qualitative analysis supported these results and further indicated that both SNS and newspapers were crucial platforms for political actors, who were involved in a series of conflicts and coalitions over the last six years. While SNS gave rise to pro-revolution actors (especially revolutionary youth) and enabled them to topple Mubarak on February 11th, 2011, newspapers and other mainstream media enabled anti-revolution actors (especially the army) to restore authority on July 3rd, 2013. Thus, it can be said that SNS were not sufficient to empower the emergent force of revolutionary youth in the long-run in the face of antirevolution actors.

The main reasons why the empowerment of revolutionary youth was obstructed, despite their strong access to SNS, are that anti-revolution actors controlled all mainstream media and practiced massive repression against opposition forces, and that SNS increasingly became available for anti-revolution actors (see, e.g., Castells, 2009, p. 414; Fenton, 2016, p. 176). These factors eventually led the anti-revolution actors to outweigh the revolutionary youth. Here, we can say that all aspects of the obstruction of PP by political regimes after July 3rd, 2013 undermined the emergence of new political actors and, at the same time, impaired the power of both revolutionary youth and the MB. Thus, it is reasonable to consider SNS a space for-not a holder of-power (Castells, 2007 , p. 242). Nevertheless, this does not negate the importance of SNS and new political actors for the alteration of staging power relationships and decision making (Castells, 2009, p. 412; Curran, 2002, p. 65).

Furthermore, the quantitative analysis showed that Egyptian youth used newspapers and SNS in relatively high rates, and the qualitative analysis pointed out that political actors have overused both channels. Newspa- 
pers were exploited, especially by the army, for fighting political battles against opposition forces. As a result, the political discourse of newspapers became highly politicized and biased, and this consequently affected their credibility. In contrast, SNS were overused, especially by revolutionary youth, as a counter-platform for information and mobilization purposes. Many aspects of PP also shifted and were practiced through SNS. Especially right after the revolution, this made the logic of SNS more prevalent than the logic of political actions, which could be considered a type of mediatization of politics.

\section{Conclusion}

This article investigated the effects of newspapers and SNS on the political participation of youth and the power relations of political actors in Egypt following the 2011 revolution. In this context, I argued that SNS cannot, in the long run, empower new political actors, especially if newspapers and other mainstream media are under the control of old actors. In order to empirically validate this argument, a survey was applied on a sample of Egyptian youth and semi-structured interviews were conducted with a number of political activists and journalists.

The results found that newspapers, but not SNS, significantly related with youth's political participation. It was also found that both newspapers and SNS were decisive platforms for enabling pro- and anti-revolution actors, as powers and counter-powers, to achieve interim political goals. Both anti-revolution actors (supported by newspapers) and pro-revolution actors (supported by SNS) were involved in a series of cooperation and conflict relationships, which eventually ended up favoring the anti-revolution actors. Thus, SNS were not sufficient to empower revolutionary youth as a new political actor in the face of anti-revolution actors, primarily due to SNS censorship and political repression.

\section{Acknowledgements}

I am very grateful to my supervisor, Norbert Wildermuth, who guided me throughout the preparation of this article. I also thank the people who responded to the questionnaire and those who accepted the request for an interview despite the risks that might have entailed.

\section{Conflict of Interests}

The author declares no conflict of interests.

\section{References}

Abd Al-samad, R. (2014, January 17). Taqrir: MosharaKat Almasryeen fi kafat alentkhabat wa Alestifitaat baad thawrat 25 yanayr [Report: Egyptian's participation in all elections and referendums after the 25 January revolution]. The Opinion. Retrieved from: http:// arrai.org/pages.php?option=browse \&id=122832
Abdulla, R. (2014). Egypt's media in the midst of revolution. Washington, DC: Carnegie Endowment for International Peace.

Alexander, A., \& Aouragh, M. (2014). Egypt's unfinished revolution: The role of the media revisited. International Journal of Communication, 8, 809-915. doi:1932-8036/20140005

Allam, R. (2010). Media landscape: Egypt. European Journalism Centre. Retrieved from http://ejc.net/ media_landscapes/egypt

AlMaskati, N. A. (2012). Newspaper coverage of the 2011 protests in Egypt. International Communication Gazette, 74(4), 342-366. doi:10.1177/ 1748048512439820

Anglim, J. (2009). Calculating composite scores of ability and other tests in SPSS. Jeromy Anglim's Blog: Psychology and Statistics. Retrieved from http://jeromy anglim.blogspot.dk/2009/03/calculating-compositescores-of-ability.html

Aouragh, M. (2012). Social media, mediation and the Arab revolutions. Triple C, 10(2), 518-536.

Aouragh, M., \& Alexander, A. (2012). The Egyptian experience: Sense and nonsense of the Internet revolution. International Journal of Communication, 5, 1344-1358. doi:1932-8036/2011FEA1344

Bakker, T. P., \& de Vreese, C. H. (2011). Good news for the future? Young people, Internet use, and political participation. Communication Research, 38(4), 451-470. doi:10.1177/0093650210381738

Bennett, W. L., \& Segerberg, A. (2012). The logic of connective action: Digital media and the personalization of contentious politics. Information, Communication \& Society, 15(5), 739-768. doi:10.1080/ 1369118X.2012.670661

Blernackl, B., \& Waldorf, D. (1981). Snowball sampling problems and techniques of chain referral sampling. Sociological Methods \& Research, 10(2), 141-163.

Budak, A. (2010). Facebook, Twitter and Barack Obama: New media and the 2008 presidential elections. (Master Thesis, UMI No. 1474900). Georgetown University, Washington, USA.

Castells, M. (2007). Communication, power and counter-power in the network society. International Journal of Communication, 1, 238-266. doi:19328036/20070238

Castells, M. (2009). Communication power. New York, NY: Oxford University Press.

Castells, M. (2011). A network theory of power. International Journal of Communication, 5, 773-787. doi:1932-8036/20110773

Charmaz, K. (2006). Constructing grounded theory: A practical guide through qualitative analysis. London: Sage Publications.

Corbin, J. M., \& Strauss, A. (1990). Grounded theory research: Procedures, canons, and evaluative criteria. Qualitative Sociology, 13(1), 3-21. doi:10.1007/bf00988593

Creswell, J. W., \& Plano Clark, V. L. (2011). Designing and 
conducting mixed methods research ( $2 \mathrm{nd}$ ed.). Thousand Oaks, CA: Sage Publications.

Curran, J. (2002). Media and power: Communication and society. New York, NY: Taylor \& Francis.

Dimitrova, D., \& Bystrom, D. (2013). The effects of social media on political participation and candidate image: Evaluations in the 2012 lowa caucuses. American Behavioral Scientist, 57(11), 1568-1583. doi:10.1177/0002764213489011

El-Adawy, A. (2014). Egypt's multiple power centers. The Washington Institute for Near East Policy. Retrieved from http://www.washingtoninstitute.org/policy-ana lysis/view/egypts-multiple-power-centers

El-dine, C. C. (2014). Fragile alliances in Egypt's postrevolutionary order: The military and its partners. Retrieved from https://www.files.ethz.ch/isn/185251/ 2014C46_chams_el_dine.pdf

Ellison, N. B., Steinfield, C., \& Lampe, C. (2007). The benefits of Facebook "friends": Social capital and college students' use of online social network sites. Journal of Computer-Mediated Communication, 12(4), 11431168. doi:10.1111/j.1083-6101.2007.00367.x

EINawawy, M., \& Khamis, S. (2012). Political activism 2.0: Comparing the role of social media in Egypt's "Facebook revolution" and Iran's "Twitter uprising". CyberOrient, 6(1). Retrieved from http://www. cyberorient.net/article.do?articleld $=7439$

Fawzy, S. (2008). Taathir kol men alitsal algamahiry wa alshaksy ala alintmaat alhizbia wa almosharka alsyasya litolab algameat almesria bialtatbiq ala intikabat almagales almahlia (April 2008): Dirasa mashie ala tolab Gameat Alkahira [The effect of mass and personal communication on partisan affiliations and political participation of Egyptian university students, the case of local elections (April 2008): A survey on Cairo university students]. The Egyptian Journal of Mass Communication Research, 30, 191-299.

Fenton, N. (2016). The internet of radical politics and social change. In J. Curran, N. Fenton, \& D. Freedman (Eds.), Misunderstanding the Internet (2nd ed., pp. 173-202). New York, NY: Routledge.

Foreman, E. K. (1991). Survey sampling principles. New York, NY: Marcel Dekker.

Freedom House. (2016). Egypt: Freedom of the press 2016. Retrieved from https://freedomhouse.org/ report/freedom-press/2016/egypt

Glaser, B. G., \& Strauss, A. L. (1967). The discovery of grounded theory, strategies for qualitative research. New Brunswick: Aldine Transaction.

Gorsche, J. (2002). Does newspaper reading still matter? Exploring the connection between the news: Media habits and political participation of Canadian youth (Unpublished Master Thesis). The University of Calgary, Ottawa, Canada.

Groshek, J. (2008). Freedom and new media: Examining the relationship between communication technologies and democracy cross-nationally from 1946 to 2003. (Doctoral Dissertation, UMI No. 3319903). In- diana University, Bloomington, USA.

Gustafsson, N. (2012). The subtle nature of Facebook politics: Swedish social network site users and political participation. New Media \& Society, 14(7), 11111127. doi:10.1177/1461444812439551

Hamdy, N., \& Gomaa, E. H. (2012). Framing the Egyptian uprising in Arabic language newspapers and social media. Journal of Communication, 62(2), 195211. doi:10.1111/j.1460-2466.2012.01637.x

Harrebye, S., \& Ejrnæs, A. (2015). European patterns of participation: How dissatisfaction motivates extraparliamentary activities given the right institutional conditions. Comparative European Politics, 13(2), 151-174. doi:10.1057/cep.2013.7

Holt, K., Shehata, A., Strömbäck, J., \& Ljungberg, E. (2013). Age and the effects of news media attention and social media use on political interest and participation: Do social media function as leveller? European Journal of Communication, 28(1), 19-34. doi:10.1177/0267323112465369

Howard, P. N. (2010). The digital origins of dictatorship and democracy: Information technology and political Islam. New York, NY: Oxford University Press.

Howard, P. N., \& Hussain, M. M. (2013). Democracy's fourth wave, digital media and the Arab Spring. Oxford: Oxford University Press.

Ibrahim, E. (2012). Newspapers coverage of the Egyptian January 25 revolution: A framing analysis. (Unpublished Master Thesis). The American University, Cairo, Egypt.

Israel, G. D. (1992, November). Determining sample size (PEOD6). Gainesville: University of Florida. Retrieved from http://www.psycholosphere.com/Determining \%20sample\%20size\%20by\%20Glen\%20lsrael.pdf

Kamel, S. H. (2014). The value of social media in Egypt's uprising and beyond. The Electronic Journal of Information Systems in Developing Countries, 60(5), 1-7. Retrieved from https://www.ejisdc.org/Ojs2/ index.php/ejisdc/article/view/1257

Khalifa, S. (2015). Egypt's lost spring: Causes and consequences. Santa Barbara, CA: Praeger.

Khamis, S. (2011). The transformative Egyptian media landscape, changes, challenges and comparative perspectives. International Journal of Communication, 5 , 1159-1177. doi:1932-8036/20111159

Khamis, S., \& Vaughn, K. (2011). Cyberactivism in the Egyptian revolution: How civic engagement and citizen journalism tilted the balance. Arab Media and Society, 14, 1-37.

Khamis, S., Gold, P. B., \& Vaughn, K. (2012). Beyond Egypt's "Facebook revolution" and Syria's "YouTube uprising": Comparing political contexts, actors and communication strategies. Arab Media \& Society, 15, $1-30$.

Mason, P. (2013). Why it's kicking off everywhere. London: Verso Books.

Meier, P. P. (2011). Do liberation technologies change the balance of power between repressive states and civil 
society? (Doctoral Dissertation, UMI No. 3499978). The Fletcher School of Law and Diplomacy, Medford, USA.

Moeller, J., De Vreese, C., Esser, F., \& Kunz, R. (2014). Pathway to political participation: The influence of online and offline news media on internal efficacy and turnout of first-time voters. American Behavioral Scientist, 58(5), 689-700. doi:10.1177/ 0002764213515220

Oser, J., Hooghe, M., \& Marien, S. (2013). Is online participation distinct from offline participation? A latent class analysis of participation types and their stratification. Political Research Quarterly, 66(1) 91-101. doi: $10.1177 / 1065912912436695$

Rice, L. L., Moffett, K. W., \& Madupalli, R. (2012). Campaign-related social networking and the political participation of college students. Social Science Computer Review, 31(3), 257-279. doi:10.1177/ 0894439312455474

Richard, D. M. (2010). Standardized score. In N. J. Salkind (Ed.), Encyclopedia of research design (pp. 14371441). Thousand Oaks, CA: Sage Publications.

Roll, S. (2014). Al-Sisi's development visions: Projects and power in Egypt (SWP Comments 26). Berlin: Stiftung Wissenschaft und Politik. Retrieved from https://www.swp-berlin.org/fileadmin/contents/pro ducts/comments/2014C26_rll.pdf

Schlozman, K., Verba, S., \& Brady, H. E. (2010). Weapon of the strong? Participatory inequality and the Internet. Perspectives on Politics, 8(2), 487-509. doi:10.1017/S1537592710001210

Schuster, J. (2013). Invisible feminists? Social media and young women's political participation. Political Science, 65(1), 8-24. doi:10.1177/0032318713486474

Shehata, A. (2010). Pathways to politics: How media system characteristics can influence socioeconomic gaps in political participation. The International Journal of Press/Politics, 15(3), 295-318. doi:10.1177/1940161209360930

Shehata, M. (2017). Are people more connective than political actions? Toward an empirical approach for connective participants. Interactions: Studies in Communication and Culture. Manuscript in preparation.
Sika, N. (2012). Youth political engagement in Egypt: From abstention to uprising. British Journal of Middle Eastern Studies, 39(2), 181-199. doi:10.1080/ 13530194.2012.709700

Strauss, A., \& Corbin, J. M. (1998). Basics of qualitative research: Techniques and procedures for developing grounded theory (2nd ed.). Thousand Oaks, CA: Sage Publications.

Valenzuela, S. (2013). Unpacking the use of social media for protest behavior: The roles of information, opinion expression, and activism. American Behavioral Scientist, 57(7), 920-942. doi:10.1177/ 0002764213479375

Verba, S., Schlozman, K. L., \& Brady, H. (2002). Voice and equality: Civic voluntarism in American politics (4th ed.). Cambridge, MA: Harvard University Press.

Vissers, S., Hooghe, M., Stolle, D., \& Mahéo, V. A. (2012). The impact of mobilization media on off-line and online participation: Are mobilization effects mediumspecific? Social Science Computer Review, 30(2), 152169. doi:10.1177/0894439310396485

Wang, Y. W. (2002). Talking, politics, and media: How does media use correlate with political talk and political participation? (Master Thesis, UMI No. 1406955). California State University, Fullerton, USA.

Williams, A. E. (2008). Engaging the electorate in an electronic age: Surveying citizens' use of digital newspapers during a presidential election. (Doctoral Dissertation, UMI No. 3305105). University of Michigan, Ann Arbor, USA.

Wimmer, R. D., \& Dominick, J. R. (2011). Mass media research: An introduction (9th ed.). Boston: Wadsworth.

Wright-Phillips, M. V. (2010). Mass media and political participation: Does news source matter? (Master Thesis, UMI No. 1482678). Southern Illinois University, Carbondale, USA.

Youssef, A. M. (2012). A critical analysis on media coverage of the Egyptian revolution: The case of Al-Ahram, Al-Masry Al-Youm, The Telegraph and The Washington Post (Unpublished Master Thesis). Örebro University, Örebro, Sweden.

\section{About the Author}

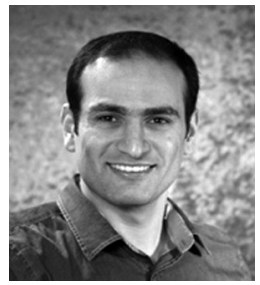

Mostafa Shehata joined Roskilde University in Denmark as a PhD candidate at the Department of Communication and Arts in 2014. He holds master's and bachelor's degrees in mass communication from Egypt. His research addresses connective action, media power, the mediatization of politics, the effects of newspapers and social network sites, and Internet-based social movements. 